NBER WORKING PAPER SERIES

\title{
DO TEACHER ABSENCES IMPACT STUDENT ACHIEVEMENT? LONGITUDINAL EVIDENCE FROM ONE URBAN SCHOOL DISTRICT
}

\author{
Raegen T. Miller \\ Richard J. Murnane \\ John B. Willett \\ Working Paper 13356 \\ http://www.nber.org/papers/w13356 \\ NATIONAL BUREAU OF ECONOMIC RESEARCH \\ 1050 Massachusetts Avenue \\ Cambridge, MA 02138 \\ August 2007
}

We thank participants at seminars and conference presentations at Harvard University, NBER,APPAM, and AEFA for their useful feedback. The views expressed herein are those of the author(s) and do not necessarily reflect the views of the National Bureau of Economic Research.

(C) 2007 by Raegen T. Miller, Richard J. Murnane, and John B. Willett. All rights reserved. Short sections of text, not to exceed two paragraphs, may be quoted without explicit permission provided that full credit, including $\odot$ notice, is given to the source. 
Do Teacher Absences Impact Student Achievement? Longitudinal Evidence from One Urban

School District

Raegen T. Miller, Richard J. Murnane, and John B. Willett

NBER Working Paper No. 13356

August 2007

JEL No. I2,J08,J22,J33,J38

\begin{abstract}
$\underline{\text { ABSTRACT }}$
Rates of employee absences and the effects of absences on productivity are topics of conversation in many organizations in many countries. One reason is that high rates of employee absence may signal weak management and poor labor-management relations. A second reason is that reducing rates of employee absence may be an effective way to improve productivity. This paper reports the results of a study of employee absences in education, a large, labor-intensive industry. Policymakers' concern with teacher absence rests on three premises: (1) that a significant portion of teachers' absences is discretionary, (2) that teachers' absences have a nontrivial impact on productivity, and (3) that feasible policy changes could reduce rates of absence among teachers. This paper presents the results of an empirical investigation of the first two of these premises; it discusses the third premise. We employ a methodology that accounts for time-invariant differences among teachers in skill and motivation. We find large variation in adjusted teacher absence rates among schools. We estimate that each 10 days of teacher absences reduce students' mathematics achievement by 3.3 percent of a standard deviation.
\end{abstract}

Raegen T. Miller

Graduate School of Education

Harvard University

6 Appian Way

Cambridge, MA 02138

millerra@mac.com

Richard J. Murnane

Graduate School of Education

Harvard University

6 Appian Way - Gutman 409

Cambridge, MA 02138

and NBER

richard_murnane@harvard.edu
John B. Willett

Graduate School of Education

Harvard University

6 Appian Way

Cambridge, MA 02138

john_willett@harvard.edu 


\section{INTRODUCTION}

Rates of employee absences and the effects of absences on productivity are topics of conversation in many organizations in many countries. One reason is that high rates of employee absence may signal weak management and poor labor-management relations. A second reason is that reducing rates of employee absence may be an effective way to improve productivity.

Education is an industry in which research on the magnitude and consequences of employee absences, in particular those of teachers, is both feasible and interesting. The feasibility stems from the ability to use student test scores, net of prior achievement, as measures of teacher productivity. The interest comes from several sources. First, most school systems contain many schools (work sites), and the quality of leadership and informal norms about attendance are likely to vary among schools. Consequently, absence rates, net of differences in the demographic characteristics of teachers, are likely to vary among schools. Exploring the reasons for the differences in school-specific teacher absence rates may provide insights about strategies to reduce absences. Second, teacher compensation accounts for more than half of public sector education budgets. There are few opportunities to substitute capital for the labor of absent teachers. Instead, substitutes, often with very little training, are typically hired at considerable expense. Third, the output of the education industry, students' skills and knowledge, are critical to both the equality of opportunity norm and the economic growth aspiration of most countries.

The concern with teacher absence rests on three premises: (1) that a significant portion of teachers' absences is discretionary, (2) that teachers' absences have a non- 
trivial impact on productivity, and (3) that feasible policy changes could reduce rates of absence among teachers. This paper presents the results of an empirical investigation of the first two of these premises; it discusses the third premise. Our data come from the education industry, but our methodology could potentially be applied to data from other industries.

The remainder of the paper is organized as follows. Section II provides background on teacher absences. Section III presents our data, describes the distribution of teacher absences, and explores determinants of teacher absence. Section IV explains the analytic strategies we use to assess the impact of teacher absence on student achievement, and Section V presents findings. Section VI discusses these findings and offers conclusions.

\section{TEACHER ABSENCES}

\section{How often are teachers absent?}

On average, public school teachers in the United States are absent five to six percent of the days schools are in session (Ballou, 1996; Podgursky, 2003). This rate of absence is low relative to those in the developing world, where teacher absence rates of 20 percent are common (Chaudhury, Hammer, Kremer, Muralidharan and Rogers (2006). However, U.S. teacher absence rates are nearly three times those of managerial and professional employees (Ballou, 1996; Podgursky, 2003). One contributing factor may be teachers' daily exposure to large numbers of children, some of whom are carriers for infectious diseases. A second is that the proportion of teachers who are female is much higher than the proportion of managerial and professional employees who are female. 
Numerous studies have documented higher rates of absence for female employees than male employees (Educational Research Service, 1980).

Do teachers exercise discretion over their absences?

A variety of evidence indicates that some teacher absences are discretionary and can be influenced by school and district policies. ${ }^{1}$ For example, teachers' rates of absence are positively associated with the generosity of available leave provisions (Ehrenberg, Ehrenberg, Rees, \& Ehrenberg, 1991; Winkler, 1980), and the number of contractually allowed days of paid sick- or personal-leave. Rates of absence drop when incentive schemes like buy-backs of unused sick-leave (Boyer, 1994; Ehrenberg et al., 1991; Winkler, 1980) or bonuses for exceptional attendance (Boyer, 1994; Freeman \& Grant, 1987; Jacobson, 1990; Skidmore, 1984; White, 1990) are implemented. Teachers respond to changes in absence control policies. For example, teachers who are required to report absences directly to their principal by telephone are absent less often than teachers who report their absences indirectly, to either a centralized reporting center or a school-based message machine (Farrell \& Stamm, 1988; Winkler, 1980).

The temporal pattern of teacher absences also suggests discretionary behavior. ${ }^{2}$ First, teachers are absent most frequently on Mondays and Fridays (Bundren, 1974; Capitan \& Morris, 1978; Educational Research Service, 1980; Malick, 1997; Pennsylvania School Boards Association, 1978), timing consistent with a desire to have . longer blocks of leisure time (Rhodes \& Steers, 1990). Second, a high proportion of

\footnotetext{
${ }^{1}$ State policies are also relevant. For example, the California state Teachers Retirement System was modified in 1997 to make more teachers eligible to purchase extra retirement benefits in proportion to their accumulated, unused sick-leave (California Assembly Bill 1102, Knox, 1997).

${ }^{2}$ We have intentionally avoided the term absenteeism for two reasons. First, the term has pejorative flavor that we do not wish to impart. Second, although the term has been used by researchers in connection with avoidable absence (Rhodes \& Steers, 1990), we do not observe the true motivation of particular absences.
} 
teacher absences are of a duration just short of that requiring medical certification of illness (Educational Research Service, 1980)), (Rhodes \& Steers, 1990).

How might teacher absences affect student achievement?

The literature on the impact of employee absences on productivity in industries apart from education provides a backdrop for the current study. In a paper published in 1983, Allen hypothesized that productivity loss from worker absences will depend on the extent to which managers can reassign workers from other positions and can find temporary replacements as productive as the absentees. In a 2006 paper, Nicholson and co-authors used results of a survey of managers in 12 industries to test a number of hypotheses similar to Allen's. They found that absences had larger negative effects on productivity the more difficult it was to find a perfect replacement, the more time sensitive the work involved, and the more the worker functioned as part of a team.

This pattern of findings suggests that the negative impact of the absences of teachers from urban elementary schools may be substantial. Good substitutes are notoriously difficult to find in urban districts. Many districts are responding to accountability pressures by pressing teachers to stick with instructional schedules aligned with state curriculum standards and the content of mandatory state tests. They are also investing in professional development that involves teachers working in teams to improve instruction and make it more consistent.

There are several mechanisms through which teacher absences may reduce student achievement. First, instructional intensity may be radically reduced when a regularly assigned teacher is absent (Capitan \& et al., 1980; Gagne, 1977; Varlas, 2001). itute teacher showing movies is a time-honored illustration, but low skill levels of 
substitute teachers may contribute to the reduction in instructional focus. In contrast to policies of similarly industrialized countries (e.g., Canada, Australia), nineteen states do not require that substitutes hold a Bachelor's degree (Henderson, Protheroe, \& Porch, 2002), much less the equivalent licensure status of the regular teacher. Furthermore, NCLB specifically exempts substitutes from its otherwise ambitious requirements for teacher quality (US Department of Education, 2004).

A second mechanism through which teacher absences may affect student achievement is through the creation of discontinuities of instruction, the disruption of the regular routines and procedures of the classroom (Rundall, 1986; Turbeville, 1987). Students may have difficulty forming meaningful relationships with multiple, mobile substitutes, and even if substitutes deliver brilliant isolated lessons, they may not be able to implement a regular teacher's long-term instructional strategies. Furthermore, substitutes' lack of detailed knowledge of students' skill levels makes it difficult for them to provide differentiated instruction that addresses the needs of individual students.

Teacher absences may also negatively impact student achievement in less direct ways. For example, teacher absences may inhibit attempts by school faculties to implement consistent instructional practices across classrooms and grades. Common planning time, during which teachers may collaborate on improving instruction, is often so scarce that even low rates of teacher absence could almost completely undermine its purpose. Note that this mechanism implies that a teacher's absence not only impacts negatively on the students he or she directly works with, but also on the students taught by the teacher's colleagues. 
Prior studies relating teacher absences to student achievement

Many studies have found a negative relationship between teacher absences and student achievement (Bayard, 2003; Beavers, 1981; Boswell, 1993; Cantrell, 2003; 2005; Lewis, 1981; Madden \& et al., 1991; Manatt, 1987; Pitkoff, 1989; Smith, 1984; Summers \& Raivetz, 1982; Womble, 2001; Woods, 1990). ${ }^{3}$ However, these studies do not provide compelling evidence of a causal link between teacher absences and student achievement because they do not deal explicitly with the potential correlation between measures of teacher absences and unobserved levels of teacher skill and effort. For example, a high rate of absence may signal a teacher's lack of skill or effort when she is in school. If this were the dominant pattern, then the observed negative relationship between teacher absence and student achievement would be an upwardly biased estimate of the causal impact of teacher absence on student achievement. Thus, the research challenge is to develop a strategy that permits unbiased estimation of the causal impact of teacher absence on student achievement.

Duflo and Hanna's (2006) experimental study, in which financial incentives for good attendance were provided to teachers in a random sample of elementary schools in rural India, provides strong evidence of a causal relationship between teacher absence and student achievement. A year after the intervention began, test scores for students in the treatment schools were substantially higher $(0.17 \mathrm{SD})$ than those of students in the control schools. This finding, however, may be peculiar to the context in which the study

\footnotetext{
${ }^{3}$ There are exceptions to this pattern. Studies that have not found a correlation between teacher absences and student achievement include (Ehrenberg et al., 1991; Kirk, 1998; New York City Public Schools, 2000; Occhino, 1987). The Ehrenberg, et al. paper, for example, used data aggregated to the level of the school district.
} 
was done. The background rate of absence was extremely high (42 percent) compared to rates observed in the US.

A study conducted by Clotfelter, Ladd, and Vigdor (2006) using data from North Carolina provides U.S.-based causal evidence that teacher absences negatively affect student achievement. Using a large dataset in which teachers were observed in multiple years, they were able to control for time-invariant skill and effort levels of teachers. Their evidence indicates that 10 additional days of teacher absences decreased student achievement by one or two percent of a standard deviation. This finding, however, speaks to the average effect across rural, suburban, and urban districts alike. Our study focuses on one urban district, where the importance of high quality instruction and the negative effects of teacher absence may be especially large because most students live in families that lack the resources to compensate for poor school-based instruction.

III. DATA

We obtained data on students and teachers from the Ormondale School District (OSD), ${ }^{4}$ a large, urban school district in the northern part of the United States. The district has nearly 80 elementary schools, with approximately 200 teachers and 4000 students at each elementary grade level. OSD has an electronic report card system in place that supports the matching of students to individual classroom teachers. The OSD Office of Human Resources provided information on each of these teacher's demographic characteristics, home ZIP-Code, absences, experience, licensure and employment status over three consecutive academic years (SY03-SY05). For the purpose of constructing a measure of the distance that a teacher commuted from home to school,

\footnotetext{
${ }^{4}$ In accordance with the wishes of district officials, Ormondale School District is a pseudonym.
} 
we obtained the geographical locations of schools from the Common Core of Data of the National Center for Education Statistics, and we purchased a commercial database that matched each ZIP-Code to the geographic latitude and longitude of its centroid. ${ }^{5}$ From the National Climatic Data Center, we obtained files containing multiple measures of daily weather conditions in the vicinity of teachers' homes. We accessed information on the enrollment and aggregate student demographics within each school from the website of Ormondale's State Department of Education.

Demographic characteristics of teachers and schools

Table 1 presents descriptive statistics on selected characteristics of 2,594 unique teachers and 75 elementary schools in which they teach. Although we only use 285 of these teachers in examining the impact of teacher absences on student achievement (those teaching fourth grade in at least one of the three years studied), ${ }^{6}$ we work with the larger group for purposes of documenting important patterns of absence. Not surprising for US elementary schools, more than 86 percent of the teachers are female. Twenty-four percent are African-American and nine percent are Hispanic. On average, teachers possessed 14 years of teaching experience. Over seven percent of teachers were in their first year of teaching, and another seven percent were in their second year. Their average length of the home-to-school commute was slightly more than seven miles, with almost eight percent commuting more than 20 miles. $^{7}$

\footnotetext{
${ }^{5}$ ZipCodeWorldTM Premium is published by Hexa Software Development Center (www.zipcodeworld.com).

${ }^{6}$ We verified that this subset of teachers is statistically representative of the larger group on observed characteristics.

${ }^{7}$ We constructed the measure of commuting distance by applying the standard formula from spherical trigonometry to the geographical coordinates (longitude, latitude) of a teacher's school and home (centroid of the home ZIP-Code).
} 
Table 1 also presents means and standard deviations for variables measured at school-level. Student enrollment for the schools in our sample ranged from 113 to 948 students, with an average of 364 students. Nine of the 75 schools in the sample have students from Kindergarten through $8^{\text {th }}$ grade, as opposed to having students from Kindergarten through $5^{\text {th }}$ grade. The demographic composition of the student body varied markedly across schools. However, in all but two of the schools, at least half of the students were students of color, and 55 of the 75 schools had a student body that was made up of more than 80 percent students of color. Other indicators showing considerable variation include the out-of-school student suspension rate (Mean=4.128; $\mathrm{SD}=4.029)$ and the student retention rate $(\mathrm{Mean}=5.067 ; \mathrm{SD}=2.493)$.

\section{Measures of teacher absences, by purpose}

In contrast to many previous studies of teacher absence, which rely on yearly aggregate measures of teacher absence, the data used in the present study include day-byday information about teachers' absences and their reported reasons for being absent. This information allows us to construct measures of absence to suit our different purposes. For the purposes of comparing rates of teacher absence between schools and exploring the determinants of absence, we first derive a measure of discretionary absences.

Two patterns suggest that discretionary absences are a significant proportion of total absences for OSD elementary school teachers. Table 2 shows the percentage of teachers reported as absent on instructional days, by weekday, over three academic years. The weekdays with the highest percentage of teachers absent are Friday (6.6 percent) and Monday (5.7 percent). In contrast, only 4.9 percent and 5.1 percent of teachers were 
absent on an average Tuesday or Wednesday, respectively. These figures suggest that some OSD teachers tend to use their leave privileges to stretch out weekends.

$<$ Table 2 about here $>$

When OSD teachers report an absence, they must provide an "excuse" code. ${ }^{8}$ Based on these codes, we constructed 16 categories of absence. Absences due to personal illness constitute almost 57 percent of the 59,600 absences we observed. Of these absences, 21,343 occur in blocks of one or two consecutive days. One explanation for the elevated percentage of teachers absent on Fridays and Mondays is that teachers take advantage of the contractual provision that they need not provide any documentation for absences of less than three days due to personal illness. ${ }^{9}$ This would explain why the proportion of absences attributed to short-term personal illness that occurred on a day adjacent to a non-instructional day $(52.3 \%)$ was higher than the 45.7 percent of all instructional days that were adjacent to a non-instructional day.

\section{$<$ Table 3 about here $>$}

The percentage of absences attributed to personal necessity that occurred on a day adjacent to a non-instructional day $(64.3 \%)$ was also considerably higher than the 45.7 percent of instructional days adjacent to non-instructional days. Conversations with school principals revealed that many teachers viewed such absences as an entitlement that they could use to fit their preferences. We combine short-term absences due to personal

\footnotetext{
${ }^{8}$ There were 46 distinct "excuse" codes, and their names provided a reasonable basis for creating less finegrained categories of absence.

${ }^{9}$ The collective bargaining agreement in operation at our research site is not specific about the number of consecutive absences due to illness that necessitate documentation. Rather, the agreement notes that building administrators may demand documentation (e.g., a note from a doctor) after a "pattern of abuse" has been established.
} 
illness and those due to personal necessity to create a measure of discretionary absences. ${ }^{10}$ We call remaining absences non-discretionary. Determinants of discretionary teacher absences

We begin by hypothesizing a regression model represented by Equation 1,

$$
D_{j k t}=\beta_{0}+\beta_{1} T_{j k t}+\beta_{2} S_{k t}+\delta_{t}+\varepsilon_{j k},
$$

where $D_{j k t}$ represents the measure of discretionary absence of teacher $j$ in school $k$ during year $t, T_{j k t}$ represents a vector of teacher characteristics, $S_{j k t}$ represents a vector of school characteristics, $\delta_{t}$ represents a set of year fixed-effects to control for district-wide trends in absence behavior, and $\varepsilon_{j k}$ represents a complex error term that respects the structure of the data. ${ }^{11}$

Table 4 displays selected results of fitting our preferred specification of the model to our dataset. Goodness-of-fit statistics show that the model accounts for 18.5 percent of the variation in discretionary absence, with 5.0 percent of the variation occurring between schools. These goodness-of-fit statistics are quite fairly stable across years.

\section{$<$ Table 4 about here $>$}

Our results are quite consistent with prior research on the determinants of teacher absence. We found that discretionary absence increases as enrollment increases, but at a

\footnotetext{
${ }^{10}$ Many of the absences captured by our measure of discretionary absences are not truly discretionary, but we make no further refinement of the measure. Based on the difference between the weighted percentage of these absences occurring on days adjacent to non-instructional days (55.9) and the expected percentage (45.7), we reckon that 3,123 of these absences (5.2 percent of the total) are truly avoidable. Using figures on substitute teachers' salaries, the direct cost of these absences is roughly $\$ 500,000$, a figure that ignores completely absences of teachers in OSD's middle schools (grades 6-8) and high schools (grades 9-12).

${ }^{11}$ By and large, an individual teacher is associated with the same school for as many years as she appears in our dataset. We follow Uribe, Murnane, Willett and Somers (2006) in using a parsimonious structure of the error term. Because 14 percent of teachers in our dataset actually change schools, we check our results with a multi-level approach to fitting models (Stata's xtmixed) that uses MLE to produce point estimates and standard errors that respect this cross-nesting. We find the simpler approach adequate for our descriptive goals here.
} 
progressively smaller rate. This finding accords with previous literature showing a positive relationship between student enrollment (school size) and teacher absence. We also found that a quadratic function of teachers' years of experience made sense in the model, thus duplicating previous findings of lower rates of discretionary absence for the very new and very experienced teachers than for teachers with moderate levels of experience. Most strikingly, our results confirm the important role of permanent employment status in predicting teachers' absence behavior. Holding all else equal, a teacher with permanent status took 3.7 more days of discretionary absence (.89 SD) than one without such status.

Consistent with prior research (Ehrenberg et al., 1991), we find that the rate of discretionary teacher absences is higher in schools with relatively low student attendance rates than in schools with high student attendance rates. We also find that teachers working in schools serving grades $\mathrm{K}-8$ tend to have lower rates of discretionary absence than teachers in $\mathrm{K}-5$ schools, holding all else equal.

\section{Adjusted school means}

To examine the extent to which the discretionary absence rate varies across schools for observationally similar teachers, we replaced the school characteristics in Equation 1 with a set of dichotomous indicators representing each school, save a reference school. We use the fitted results from this model to extract school-level means on the outcome variable (discretionary absence), adjusted for individual teacher characteristics. Figure 1 displays these adjusted means as vertical bars whose heights are measured in days of discretionary absence. The overall mean, shown as a solid black bar, is 5.13 days ( $\mathrm{SD}=1.12)$. Three schools' adjusted averages exceed 7 days; in four schools 
the adjusted average is less than 3 days. This school-specific variation is consistent with prior research arguing that informal set of school-specific cultural norms influence teachers' absence behavior. ${ }^{12}$ Our conversations with principals from four of the elementary schools in our sample suggest that high-quality, continuous leadership is critical to creating cultural norms that discourage discretionary absences. For instance, two of the principals said that they require teachers to call them directly on the morning of an absence.

$<$ Figure 1 about here $>$

\section{Student achievement and demographic characteristics}

Our analytic dataset contains detailed information on a sample of 8,631 unique students who were in the fourth grade in one or more of the three academic years studied. Table 5 presents descriptive statistics for these students. Our primary outcome variable, student achievement in mathematics, is based on scores obtained on state-sponsored assessments administered to fourth-grade students in early May. We also used scores on the state-sponsored English Language Arts examinations as outcomes. The dataset also includes students' scores on Stanford Achievement Tests (Series-9) of mathematics and reading that the students took while they were in third grade. We treated these prior measures as covariates in our regression analyses. For the 7 percent of students in our sample who repeated $3^{\text {rd }}$ grade, we used the highest available score to represent their prior achievement, by domain.

\footnotetext{
${ }^{12}$ Chadwick-Jones, Nicholson, and Brown (1982) elaborated a theory of absence culture, refined by Nicholson and Johns (1985), with two dimensions: (1) the strength of the school-level norms in determining individual absence behavior, and (2) the level of trust that teachers feel extended to them by their schools' administrators. See Martocchio (1994) or Xie and Johns (2000) for empirical work that uses this theory explicitly.
} 
$<$ Table 5 about here $>$

Our dataset also contains a variety of student-level demographic and programmatic variables that we included as covariates in our analyses. Demographic controls include: (a) a vector of dichotomous indicators of student race/ethnicity (African-American, Asian, Hispanic, White), (b) student gender, (c) whether English was the student's first language, (d) whether the student received Special Education and Related Services, and (e) whether a student was eligible for free or reduced-price lunch. As indicated by the summary statistics presented in Table 5, our analytic sample primarily contains disadvantaged students. More than 83 percent of the students were eligible for a free or reduced-price lunch, 34 percent had a first language other than English, and 13 percent received Special Education. Our sample also consisted primarily of students of color: 47 percent of the students were African-American, 29 percent were Hispanic, and 9 percent were of Asian background.

Finally, we constructed additional student-level covariates to account for important facets of the students' academic participation. Using information on each student's date of enrollment in OSD, we constructed dichotomous indicators of whether students entered their fourth grade classes after particular points in the school year. Students who entered classes late in the academic year may have differed from other students in the extent to which their fourth grade instruction was provided by the teachers in our dataset. Additionally, these students may not have experienced some portion of the teacher absences that provide the focus of our inquiry. We also constructed indicators of whether students had repeated third grade, and whether they were repeating fourth grade in the current year. 


\section{METHOD}

Our investigation of the causal impact of teacher absence on student achievement was conducted in a student-teacher-year dataset, in which there was a single record ("row") of information for each student, $i$, with each teacher, $j$, in each year, $t$. In our baseline hypothesized regression model, we specified that student mathematics achievement depended on teacher absence, as seen in Equation 2,

$$
Y_{i j k t}=\beta_{0}+\beta_{1} A_{j k t}+\beta_{2} T_{j k t}+\beta_{3} S_{i j k t}+\delta_{t}+\varepsilon_{i j k},
$$

where $Y_{i j k t}$ is the mathematics achievement of student $i$, taught by teacher $j$ in school $k$ in year $t$. The predictor of interest, $A_{j k t}$, represents the number of days that the teacher $j$ was absent from her class in year $t$ before the administration of the achievement test. The $T_{j k t}$ is a vector of teacher characteristics (ethnicity, gender, years of experience, licensure status, tenure status, commuting distance, classroom student turn-over rate) and school characteristics (enrollment, range of grades, suspension rate and student attendance rate). The $S_{i j k t}$ is a vector of student characteristics (ethnicity, gender, poverty status, language status, disability status, grade repetition status and measures of prior achievement), and the $\delta_{t}$ represents a set of year fixed effects to account for district-wide trends in teacher absence and student achievement. ${ }^{13}$ The $\varepsilon_{i j k}$ is a complex error term. ${ }^{14}$

\footnotetext{
${ }^{13}$ In SY03, teachers had access to 3 days of personal necessity leave, but in later years, this figure increased to four days. With respect to achievement, OSD systematically strove to produce improvements in all schools during the years we studied with heavy investments in professional development, particularly around implementation of a standards-oriented mathematics curriculum. Thus, allowing for different average levels of achievement, by year, makes analytical sense.

${ }^{14}$ In an analytic appendix to their 2006 article, Uribe, Murnane, Willett and Somers explain alternative ways of specifying and fitting models to account for multilevel structures in data. We opted for a parsimonious error structure (random intercepts).
} 


\section{Threats to validity}

Estimates of $\beta_{1}$ obtained by OLS estimation of Equation 2 may be biased because rates of teacher absence may be correlated with unobserved levels of teacher skill or effort. Our primary strategy for dealing with this potential problem is to fit a variant of Equation 2 in which the time-invariant teacher characteristics are replaced by dichotomous indicators representing each teacher (fixed-effects), save a reference teacher. This is a powerful strategy because the teacher-specific fixed effects absorb all time-invariant teacher skills and effort levels. Of course, since this strategy involves the estimation of $\beta_{1}$ using only year-to-year variation in absences for the same teacher, we can only fit this version of Equation 2 for teachers who appear in the dataset for more than one academic year.

While powerful, the teacher fixed effects strategy does not deal with potential bias that may be introduced by time-varying differences in unobserved teacher or effort skill levels that may be correlated with teacher absences. For example, a teacher with a critically ill family member during the current academic year may be absent from school more days than during the previous academic year. However, weaker performance by her students in the current year than in the previous year may reflect not only her absences from school, but possibly her low energy levels and high stress levels when she is in class. To address potential bias due to unobserved, time-varying correlates of student achievement and teacher absence, we use an instrumental variables (IV) strategy.

In an attempt to address this threat to validity, we employed a unique two-stage least squares (2SLS) estimation strategy. Our instrumental variables derive from the idea that bad weather may inhibit teachers' willingness or ability to attend school. We used 
principal components analysis to generate an index of the difficulty of daily driving conditions in each teacher's home from information on maximum temperature, minimum temperature, snowfall, and accumulated snowfall.

We use a two-stage least squares approach (2SLS) to implementing our IV strategy. First, we estimate a model represented by Equation 3,

$$
A B S E N T_{j k t d}=\alpha_{0}+\alpha_{1} W_{j k t d}+\alpha_{3} X+\eta_{j k t d}
$$

where $A B S E N T_{j k t d}$ is a dichotomous indicator of whether teacher $j$ was absent from school $k$ in year $t$ on day $d .{ }^{15}$ The $\mathrm{X}$ is a vector representing predictors appearing in Equation 2 other than teacher absences, ${ }^{16}$ and the $W_{j k t d}$ is a vector that includes the index of weather conditions in the teacher's home community, the teacher's commuting distance, and the interaction of the weather index and the length of commute. Fitted values of the outcome (the probability that a teacher was absent from school on a given school day) are aggregated to the school year to generate a predicted number of teacher absences for the school year (excluding days that occur after the spring student exam date). Since daily weather in the vicinity of teachers' homes is neither correlated with nor can directly influence yearly measures of student achievement, these aggregates constitute a measure of teacher absence that plausibly removes the threat to validity posed by unobserved, time-varying levels of teacher skill and effort, as described above. Figure 2 illustrates the intuitive appeal of this instrument in our first stage predictions. Each bar represents the average predicted value (response probability) of daily absence within bins defined by

\footnotetext{
${ }^{15}$ We estimated these stage-one models using OLS methods for computational reasons. Methods relying on MLA (e.g., logit) impose extraordinary computational time, owing to the size of the teacher-day dataset to which the models are fitted. An important implication of our choice is that we handle appropriately any response probabilities outside the interval $[0,1]$.

${ }^{16}$ Classroom mean values are used in the case of student-level information.
} 
foulness of weather and the length of a teacher's commute to school. That the heights of the bars tend to increase with severity of the weather, from front to back, and the height of the bars also increases with commuting distance, from left to right, shows that the weather index and its interaction with commuting distance play a useful role in predicting daily absence. In our second stage, we refit Equation 2, replacing the original measure of teacher absence with the aggregated predictions from the first stage, thus yielding new estimates of $\beta_{1}$. We adjusted the standard errors to account for the two-step procedure.

\section{RESULTS}

Table 6 presents parameter estimates, robust standard errors approximate pvalues, and goodness-of-fit statistics from fitting the model in Equation 2 using our two analytic strategies. The columns of this table are labeled 1(a) through 1(d). Column 1(a) contains $O L S$-estimates of the parameters in Equation 1 based on information on all 285 teachers who taught fourth grade in at least one academic year. Column 1(b) presents $O L S$-estimates of the parameters in the same model, but using only the sample of 144 teachers who taught fourth grade in more than one academic year. We provide this column of estimates to facilitate comparison with those in Column 1(c), which are the estimates from fitting the version of the model that includes fixed effects for teachers. The results reported in Columns 1(b) and 1(c) are based on the same sample of teachers and students. The estimates reported in Column 1(d) come from the second stage of our IV strategy. 
As indicated in column 1(a) of Table 6, the OLS estimate of the impact of teacher absences on students' mathematics achievement is negative and significantly different from zero at the .01-level. When this model is refitted using only data on the sample of 144 teachers who taught fourth grade in more than one year, the estimated absence parameter retains a negative sign, has a somewhat smaller magnitude, and retains statistical significance $(p<.05)$. The fixed effect estimate in column 1(c) is identical in sign, magnitude, and statistical significance to the one in column 1(b).

We also fitted models in which the students' scores on the state fourth grade English Language Arts (ELA) examination provided the outcome measure. The estimates of interest were consistently negative, but were smaller in magnitude and less precise than the estimates obtained when mathematics achievement was the outcome. ${ }^{17}$ This pattern raises the question of why teacher absences would influence students' mathematics achievement more than their ELA achievement. To gain some insight into the answer to this question, we conducted interviews with four elementary school principals in the OSD. They told us that in SY01 OSD had adopted a new elementary school mathematics curriculum that placed great emphasis on developing children's mathematical problem-solving skills, their ability to make use of alternative computational algorithms, and their ability to explain their reasoning processes in writing. Teaching the new mathematics curriculum successfully required the development of new teaching skills for most OSD elementary school teachers. The district invested heavily in mathematics coaches and in summer training institutes to provide OSD's elementary with the requisite skills. The net effect of the new

\footnotetext{
${ }^{17}$ Tables providing these results are available from the authors.
} 
mathematics curriculum and the retraining of OSD's elementary school teacherstraining that was not received by OSD substitute teachers - is that the gap in instructional quality in mathematics when a fourth grade teacher was replaced by a substitute teacher was particularly large. This explanation for the larger impact of absences on students' math skills than on their English language arts skills is consistent with Nicholson et al.'s findings on other industries reported above.

Other estimates presented in Table 6 support the findings of previous studies. Like Rockoff (2004) and Kane, Rockoff, and Staiger (2006), we found that teacher experience has a non-linear relationship with student achievement. Based on estimates from Column 1(c), students with a teacher who has 1 or 2 years of experience scored 33 percent of a standard deviation below students with teachers who had 10 or more years of experience, and students with a teacher who has 3 or 4 years of experience scored 23 percent of a standard deviation below students with teachers who had 10 or more years of experience. The comparable deficit for students whose teachers have between 5 and 9 years of experience is statistically indistinguishable from zero. We take these results as evidence that teachers face a steep learning curve when they begin service, but that their instructional prowess peaks between their $5^{\text {th }}$ and $9^{\text {th }}$ year in the classroom.

As mentioned above, even though the fixed effects estimate controls for potential time-invariant differences among teachers in unobserved skill and effort levels, it does not control for time-varying differences other than those captured by the time-varying measure of teacher experience. To address this problem, we implemented the IV strategy described above. The estimated impact of teacher absences on student achievement using the IV approach was consistently negative, with a magnitude between approximately two 
and four times the size of the OLS estimate. ${ }^{18}$ The value of the point estimate suggests that in years in which particular teachers were absent from school more than was typical for them, they were not less effective when they were present. Unfortunately, the standard error associated with the IV estimate of the impact of teacher absences on student achievement is too large to be able to reject the null hypothesis of no impact. A likely explanation is that our IV is a relatively weak instrument and we needed a much larger sample of teachers and students to estimate a statistically significant impact.

We conducted several sensitivity tests to determine if our primary findings (displayed in Table 6) are robust. First, we assessed whether the teachers exhibiting the most extreme absence behavior drove the findings. To do this, we omitted teachers with pre-test absences in excess of $63\left(99^{\text {th }}\right.$ percentile) from the dataset and refitted the various models. The results for the remaining teachers are hardly different from those presented in column 1(a) of Table 6 . However, the loss of teachers led to larger estimated standard errors in columns $1(b)$ and $1(c)$ and a loss of statistical significance $(\mathrm{p} \approx 13)$. Second, we omitted the 19 percent of students who were missing values on one or the other of our measures of prior achievement. The resulting parameter estimates were identical in sign and similar in magnitude to their analogues presented in Tables 7; standard errors were, of course, larger. Third, we omitted the classrooms corresponding to the 3 percent of teachers for whom we imputed values of teaching experience. Corresponding results were nearly identical in all respects to those presented in Tables 7. Finally, in four successive

\footnotetext{
${ }^{18}$ The estimated effect of teacher absence shown in Column 1(d) has a magnitude over four times the corresponding estimate in Column 1(c). When we fit stage one differently, omitting classroom means of the variables observed at the student-year level, the estimate fall to roughly twice the size of the one in Column 1(c). A note to the table in Appendix B elaborates on the conundrum posed by the different units of analysis in the two stages of our IV strategy.
} 
steps, we omitted from the dataset students who entered their classes after January 15 , December 15, November 15, and October 15, each time refitting the models embodying our analytic strategies. These results were very close to those presented in Table 6 .

\section{DISCUSSION}

\section{Contribution}

Our paper adds to the small literature examining the causal effects of teacher absences. Our focus on a single large urban district enabled us to document important patterns of absence based on local school calendars (including snow-days) and a single collective bargaining agreement. Our interviews with principals in four of the schools in our research site provided interpretations of teacher absence patterns and especially a compelling explanation for why teacher absences in OSD affected students' mathematics achievement more than their ELA achievement.

\section{Non-trivial impact}

We believe that our estimate that 10 additional days of teacher absence reduce student achievement in fourth grade mathematics by 3.3 percent of a standard deviation is large enough to be of policy relevance. One reason is that teacher absences directly affect the achievement of as many as 25 students. A second is that by reducing the efficacy of regularly scheduled team planning and professional development sessions, a teacher's absences may have an indirect negative impact on the students of the teacher's colleagues. Third, small differences in the performance of even a few students on the state's mathematics examination can result in the school not meeting the "Adequate Yearly Progress" mandate of No Child Left Behind. 


\section{Potential policy implications}

Since our study did not examine the impact of particular policies aimed at altering the distribution of teacher absences, it cannot provide evidence on the consequences of policy changes. However, our evidence that teacher absences do affect student achievement makes it worthwhile to review briefly existing evidence on the effects of school and district policies on the distribution of teacher absences. Teachers' rates of absence are positively associated with the generosity of leave provisions, such as the number of contractually allowed days of paid sick- or personal-leave (Ehrenberg et al., 1991; Winkler, 1980). Rates of absence drop when incentive schemes like buy-backs of unused sick leave or bonuses for exceptional attendance are implemented (Boyer, 1994; Ehrenberg et al., 1991; Freeman \& Grant, 1987; Jacobson, 1990; Skidmore, 1984; White, 1990; Winkler, 1980).

Another previously reported finding is particularly salient. Teachers who are required to report absences directly to their principal by telephone are absent less often than teachers who can report their absences indirectly via a centralized reporting center or a school-based message machine (Farrell \& Stamm, 1988; Winkler, 1980). Ironically, the planned implementation of a web-based absence reporting system in OSD will undercut the practice of two of the four principals we interviewed who require that teachers report absences directly to them by telephone.

\section{Future Research}

Advances in administrative record keeping will make it possible in the near future to improve studies of the impact of teacher absence on student achievement. First, information on the characteristics of substitute teachers matched to teacher absences will 
allow researchers to explore possible heterogeneity of effects due to differences in substitutes. Web-based absence reporting and substitute assignment systems promise to make such data available in the near future. Second, perhaps the greatest tool for assessing productivity costs of teacher absences will be frequent measures of student achievement. The increasing use of computer-based benchmark assessments administered throughout the school year should provide such data in the near future. 


\section{REFERENCES}

Allen, S. G. (1983). How Much Does Absenteeism Cost? Journal of Human Resources, 18(3), 379-393.

Ballou, D. (1996). The condition of urban school finance: efficient resource allocation in urban schools: National Center for Education Statistics.

Bayard, S. R. (2003). A study of the relationship between teacher absenteeism, teacher attributes, school schedule and student achievement. Unpublished Ed.D, Florida Atlantic University.

Beavers, H. J. (1981). The Relationship between Selected Educational Variables and Student Achievement in a Selected School District. Unpublished Ed.D, East Texas State University.

Boswell, C. B. (1993). The relationship between teacher absenteeism and student achievement in secondary schools in South Carolina. Unpublished Ed.D, University of South Carolina.

Boyer, C. E. (1994). The Relationship between Buy-Back Provisions and Teacher Attendance Rates. Georgia.

Bundren, D. L. (1974). The influence of situational and demographic factors on the absentee patterns of teachers. University of Southern California.

Cantrell, S. (2003). Pay and performance: the utility of teacher experience, education, credentials, and attendance as predictors of student achievement at elementary schools in LAUSD. Los Angeles, CA: Los Angeles Unified School District, Program Evaluation and Research Branch.

Capitan, J. H., \& et al. (1980). Teacher Absenteeism. A Study of the Ohio Association of School Personnel Administrators. Ohio: American Association of School Personnel Administrators, Seven Hills, OH.

Capitan, J. H., \& Morris, R. (1978, October). The Ohio report on teacher absenteeism. Paper presented at the American Association of School Personnel Administrators.

Chadwick-Jones, J. K., Nicholson, N., \& Brown, C. (1982). Social psychology of absenteeism. New York, N.Y.: Praeger. 
Chaudhury, N., Hammer, J., Kremer, M., Muralidharan, K., \& Rogers, F. H. (2006). Missing in Action: Teacher and Health Worker Absence in Developing Countries. Journal of Economic Perspectives, 20(1), 91-116.

Clotfelter, C. T., Ladd, H. F., \& Vigdor, J. L. (2006). Teacher absences: importance, incidence, and consequence. Paper presented at the Association for Public Policy Analysis and Management.

Duflo, E., \& Hanna, R. (2006). Monitoring Works: Getting Teachers to Come to School: C.E.P.R. Discussion Papers CEPR Discussion Papers: 5426.

Educational Research Service. (1980). Employee absenteeism : a summary of research. Arlington, Va.: Educational Research Service.

Ehrenberg, R. G., Ehrenberg, R. A., Rees, D. I., \& Ehrenberg, E. L. (1991). School District Leave Policies, Teacher Absenteeism, and Student Achievement. Journal of Human Resources, 26(1), 72-105.

Farrell, D., \& Stamm, C. (1988). Meta-analysis of the correlates of employee absence. Human Relations, 41(3), 211.

Freeman, R., \& Grant, F. (1987). How we increased staff attendance by 16 percent and saved \$156,000. American School Board Journal, 174(2), 31.

Gagne, R. M. (1977). The conditions of learning (3d ed.). New York: Holt Rinehart and Winston.

Henderson, E., Protheroe, N., \& Porch, S. (2002). Developing an effective substitute teacher program. Arlington, VA.: Educational Research Service.

Jacobson, S. L. (1990). Attendance Incentives and Teacher Absenteeism. Planning and Changing, 21(2), 78-93.

Kirk, C. L. (1998). Teacher absenteeism and student achievement. Unpublished Ed.D, Florida Atlantic University.

Krishnan, P., Habyarimana, J., Dercon, S., \& Das, J. (2005). Teacher shocks and student learning: evidence from Zambia: The World Bank Policy Research Working Paper Series: 3602.

Lewis, J., Jr. (1981). Do You Encourage Teacher Absenteeism? American School Board Journal, 168(11), 29-30,40. 
Ludwig, J., \& Bassi, L. J. (1999). The puzzling case of school resources and student achievement. Educational Evaluation and Policy Analysis, 21(4), 385-403.

Madden, H. D., \& et al. (1991). Teacher Absences: Are There Implications for Educational Restructuring? South Carolina.

Malick, J. J. (1997). The relationship of situational and demographic variables to staff attendance and utilization of available absence leave. Unpublished Ed.D, University of Delaware.

Manatt, R. P. (1987). Lessons from a Comprehensive Performance Appraisal Project. Educational Leadership, 7(44), 7p.

Martocchio, J. (1994). The effects of absence culture on individual absence. Human Relations, 47(3), 243.

New York City Public Schools. (2000). Impact of Student Attendance, Teacher Certification and Teacher Absence on Reading and Mathematics Performance in Elementary and Middle Schools in New York City. Flash Research Report \#3.

Nicholson, N., \& Johns, G. (1985). The Absence Culture and the Psychological ContractWho's in Control of Absence? Academy of Management Review, 10(3), 397-407.

Nicholson, S., Pauly, M. V., Polsky, D., Sharda, C., Szrek, H., \& Berger, M. L. (2006). Measuring the Effects of Work Loss on Productivity with Team Production. Health Economics, 15(2), 111-123.

Occhino, J. C. (1987). Teacher Absenteeism: Its Relationship to Student Attendance and Performance on a Standardized Achievement Test. Unpublished Ed.D, The University of Rochester.

Pennsylvania School Boards Association. (1978). Teacher absenteeism: professional staff absence study. Harrisburg, PA: Pennsylvania School Boards Association.

Pitkoff, E. (1989). Absenteeism among urban high school employees: Organizational variables. Unpublished Ed.D, Columbia University Teachers College.

Podgursky, M. (2003). Fringe benefits. Education Next(Summer).

Rhodes, S., \& Steers, R. (1990). Managing employee absenteeism. Reading, MA: Addison-Wesley Publishing Company, Inc. 
Rundall, R. A. (1986). Continuity in Subbing: Problems and Solutions. Clearing House, 59(5), 240.

Skidmore, D. E. (1984). We Used These Few Simple Steps to Cut Teacher Absenteeism in Half--And Increased Productive Class Time and Community Support in the Bargain. American School Board Journal, 171(3), 40-41.

Smith, D. B. (1984). A Study of the Relationship between Elementary Teacher Absenteeism and the Achievement of Elementary Pupils in Reading and Mathematics. Unpublished PhD, Michigan State University.

Summers, A., \& Raivetz, M. (1982). What helps fourth grade students to read? In A. Summers (Ed.), Productivity Assessment in Education. San Francisco, CA: Jossey-Bass.

Turbeville, I. F. (1987). The Relationship of Selected Teacher Characteristics on Teacher Absenteeism in Selected School Districts of South Carolina. Unpublished PhD, University of South Carolina.

Uribe, C., Murnane, R. J., Willett, J. B., \& Somers, M.-A. (2006). Expanding school enrollment by subsidizing private schools: lessons from Bogotá. Comparative Education Review, 50(2).

US Department of Education. (2004). No child left behind: a toolkit for teachers. Washington, DC: US Department of Education.

Varlas, L. (2001). Succeeding with substitute teachers. Education Update, 43(7).

White, N. A. (1990). Cut Sick-Pay a Day: An Incentive Plan To Reduce Teacher Absenteeism. A Practicum Report. Florida.

Winkler, D. R. (1980). The Effects of Sick-Leave Policy on Teacher Absenteeism. Industrial \& Labor Relations Review, 33(2), 232-240.

Womble, M. (2001). Teacher absenteeism: the relationship between teacher absence due to illness and school performance level ranking on the 1998-1999 North Carolina ABCs accountability K-8 plan model. East Carolina University.

Woods, R. C. (1990). The effect of teacher attendance on student achievement in two selected school districts. Unpublished Ed.D, Ball State University. 
Xie, J. L., \& Johns, G. (2000). Interactive effects of absence culture salience and group cohesiveness: A multi-level and cross-level analysis of work absenteeism in the Chinese context. Journal of Occupational and Organizational Psychology, 73(1), $31-52$. 


\section{TABLES AND FIGURES}

Table 1. Means and standard deviations on selected characteristics of 2594 unique teachers and their 75 schools over three academic years (SY03-SY05).

\begin{tabular}{|c|c|c|}
\hline Variable & Mean & SD \\
\hline \multicolumn{3}{|l|}{ TEACHERS } \\
\hline Discretionary absences (days per year) & 4.581 & 4.140 \\
\hline Distance commuted (miles) & 7.32 & 7.752 \\
\hline Teaching experience (years) & 13.832 & 11.884 \\
\hline Permanent employment status & 0.620 & - \\
\hline Licensed & 0.864 & - \\
\hline Male & 0.136 & - \\
\hline Asian & 0.042 & - \\
\hline African-American & 0.242 & - \\
\hline Hispanic & 0.091 & - \\
\hline Native-American & 0.003 & - \\
\hline White & 0.623 & - \\
\hline \multicolumn{3}{|l|}{ SCHOOLS } \\
\hline Enrollment (students) & 363.96 & 191.946 \\
\hline Attendance rate $^{\mathrm{a}}$ & 94.64 & 1.189 \\
\hline Suspension rate ${ }^{\mathrm{b}}$ & 4.128 & 4.029 \\
\hline Retention rate $^{c}$ & 5.067 & 2.493 \\
\hline Poverty rate ${ }^{\mathrm{d}}$ & 79.888 & 10.816 \\
\hline $\operatorname{Asian}^{\mathrm{e}}$ & 6.743 & 10.218 \\
\hline African-American ${ }^{\mathrm{e}}$ & 47.625 & 24.45 \\
\hline Hispanic $^{\mathrm{e}}$ & 30.125 & 21.412 \\
\hline Native-American $^{\mathrm{e}}$ & 0.497 & 0.575 \\
\hline White $^{\mathrm{e}}$ & 15.01 & 13.341 \\
\hline School with grades ranging from $K-8^{f}$ & 0.12 & - \\
\hline
\end{tabular}

Notes:

a. Percentage of days attended by students.

b. Percentage of students who received one or more out-of-school suspensions.

c. Percentage of students who were repeating the grade in where they were enrolled.

d. Percentage of students eligible for free or reduced-priced lunch program.

e. Percentage of students of named ethnicity.

f. Grade ranges are $\mathrm{K}-8$ or $\mathrm{K}-5$ 
Table 2. Proportion of teachers absent on instructional days, by weekday (2594 unique teachers over three academic years).

\begin{tabular}{lr}
\hline Weekday & Proportion \\
\hline Monday & 0.057 \\
Tuesday & 0.049 \\
Wednesday & 0.051 \\
Thursday & 0.053 \\
Friday & 0.066 \\
& \\
Total & 0.055 \\
\hline
\end{tabular}


Table 3. Number of absences observed and proportion of absences observed on days adjacent to non-instructional days, ${ }^{a}$ by type of absence. The proportion of instructional days adjacent to non-instructional days is 0.457. (2,594 unique teachers over three academic years)

\begin{tabular}{lrr}
\hline \hline Type of absence & $\mathrm{N}$ & Proportion \\
\hline Religious observance & 258 & 0.752 \\
Personal necessity & 9,238 & 0.643 \\
Short-term personal illness (1 or 2 consecutive days) & 21,343 & 0.523 \\
Death in the family & 2,084 & 0.476 \\
Adoption & 136 & 0.463 \\
Other & 1,163 & 0.454 \\
Workplace injury & 31 & 0.452 \\
Critical family illness & 1,054 & 0.448 \\
Maternity leave & 3,261 & 0.445 \\
Union business & 1,162 & 0.444 \\
No pay & 885 & 0.429 \\
Cancer screen & 150 & 0.427 \\
Medium-term personal illness & 12,407 & 0.416 \\
Professional conference & 5,618 & 0.397 \\
Military duty & 53 & 0.358 \\
Court appearance & 757 & 0.358 \\
& & \\
Total & 59,600 & 0.494 \\
\hline \hline
\end{tabular}

Notes:

a. Non-instructional days include Saturdays, Sundays, holidays, professional development days and snow-days.

b. This category includes, for example, absences taken to visit the school of a teacher's child under the provisions of the Family and Medical Leave Act of 1993 as well as absences that were coded in two ways (e.g., 3 hours for cancer screen and 4 hours for personal day). 
Table 4. Selected parameter estimates, robust standard errors, approximate p-values, and goodness-of-fit statistics for a regression model fit to a dataset in which a the unit of analysis is a teacher-year and the outcome is a measure of discretionary teacher absence.

\begin{tabular}{lcc}
\hline Predictor & $\begin{array}{c}\text { Parameter } \\
\text { estimate }\end{array}$ & $\begin{array}{c}\text { Robust } \\
\text { standard error }\end{array}$ \\
\hline School with grades ranging from K-8 & $-0.697^{*}$ & 0.345 \\
Log of enrollment & $0.591^{* *}$ & 0.225 \\
Student attendance rate & $-0.217^{* *}$ & 0.060 \\
Male teacher & $0.383 \sim$ & 0.056 \\
Permanent employment status & $3.702^{* *}$ & 0.193 \\
Years of experience/10 & $0.830^{* *}$ & 0.021 \\
Square of years of experience/10 & $-0.268^{* *}$ & 0.054 \\
Asian teacher & $-0.942^{* *}$ & 0.256 \\
Black teacher & $1.002^{* *}$ & 0.166 \\
Hispanic teacher & $0.711^{*}$ & 0.289 \\
Native American teacher & $1.333^{*}$ & 0.588 \\
Constant & $22.033^{* *}$ & 6.033 \\
\hline Teacher-year observations & 5961 & \\
Unique Schools & 75 & \\
Between-school variance & 0.686 & \\
Within school variance & 12.960 & \\
Intraclass correlation & 0.050 & \\
Between school R-squared & 0.355 & \\
Within school R-squared & 0.167 & \\
Overall R-squared & 0.185 & \\
\hline \hline
\end{tabular}

$\sim \mathrm{p}<.1 ; * \mathrm{p}<.05 ; * * \mathrm{p}<.01$ 
Table 5. Means and standard deviations on selected characteristics of 8,631 unique students and 280 unique teachers over three academic years (SY03-SYO5). ${ }^{a}$

\begin{tabular}{|c|c|c|}
\hline Variable & Mean & SD \\
\hline Mathematics achievement score $^{\mathrm{b}}$ & -0.264 & 1.001 \\
\hline English Language Arts achievement score ${ }^{\mathrm{b}}$ & -0.436 & 0.998 \\
\hline Female & 0.505 & - \\
\hline First language is English & 0.663 & - \\
\hline Asian & 0.094 & - \\
\hline African-American & 0.474 & - \\
\hline Hispanic & 0.293 & - \\
\hline White & 0.139 & - \\
\hline Repeated $3^{\text {rd }}$ grade & 0.072 & - \\
\hline Repeating $4^{\text {th }}$ grade & 0.032 & - \\
\hline Eligible for free or reduced-price lunch & 0.827 & - \\
\hline Receives Special Education (substantially included ${ }^{c}$ ) & 0.083 & - \\
\hline Receives Special Education (less included ${ }^{c}$ ) & 0.047 & - \\
\hline
\end{tabular}

Notes:

a. We do not present descriptive statistics for our measures of students' prior achievement, SAT-9 test scores for mathematics and reading obtained when students were in $3^{\text {rd }}$ grade. We standardize these scores to make use of quadratic and cubic terms more convenient in regression models.

b. We standardized achievement scores using information on the whole population of test-takers. The means in the analytic sample, therefore, reflect the "achievement gap", which is associated with the fact that our research site comprises primarily students living in poverty $(82.8 \%)$ and students of color $(86.2 \%)$.

c. We partition the students receiving Special Education and Related Services into two groups. Substantially included students spend at least $75 \%$ of their time in the regular classroom setting (learning from the teachers in our dataset to whom the student is matched). The other group consists of students who spend less than $75 \%$ of their time in the regular classroom. 
Table 6. Selected parameter estimates, [robust standard errors], approximate p-values, and goodness-of-fit statistics for a sequence of regression models fit to a dataset in which a the unit of analysis is a student-year and the outcome is measured achievement in mathematics.

\begin{tabular}{|c|c|c|c|c|}
\hline \multirow[b]{3}{*}{ Predictor } & OLS & OLS & OLS & 2 SLS \\
\hline & $\begin{array}{l}\text { Fixed- } \\
\text { effects of } \\
\text { teachers }\end{array}$ & & & \\
\hline & $\begin{array}{c}\text { no } \\
\text { 1(a) }\end{array}$ & $\begin{array}{c}\text { no } \\
\text { 1(b) }\end{array}$ & $\begin{array}{l}\text { yes } \\
1(\mathrm{c})\end{array}$ & $\begin{array}{c}\text { no } \\
\text { 1(d) }\end{array}$ \\
\hline Teacher absences (days before test) & $\begin{array}{c}-0.0040^{* *} \\
{[0.0012]}\end{array}$ & $\begin{array}{c}-0.0033 * \\
{[0.0013]}\end{array}$ & $\begin{array}{c}-0.0033 * \\
{[0.0016]}\end{array}$ & $\begin{array}{c}-0.0175 \\
{[0.0114]}\end{array}$ \\
\hline Teacher has 1 or 2 years of experience ${ }^{a}$ & $\begin{array}{c}-0.1775 * * \\
{[0.0527]}\end{array}$ & $\begin{array}{c}-0.3430^{* *} \\
{[0.0831]}\end{array}$ & $\begin{array}{c}-0.3315^{*} \\
{[0.1472]}\end{array}$ & $\begin{array}{c}-0.1838^{* *} \\
{[0.0546]}\end{array}$ \\
\hline Teacher has 3 or 4 years of experience & $\begin{array}{c}-0.1574 * * \\
{[0.0527]}\end{array}$ & $\begin{array}{c}-0.2607 * * \\
{[0.0643]}\end{array}$ & $\begin{array}{l}-0.2281^{*} \\
{[0.1109]}\end{array}$ & $\begin{array}{l}-0.1684^{* *} \\
{[0.0546]}\end{array}$ \\
\hline Teacher has 5 to 9 years of experience & $\begin{array}{c}-0.0432 \\
{[0.0481]}\end{array}$ & $\begin{array}{l}-0.1070^{*} \\
{[0.0521]}\end{array}$ & $\begin{array}{c}-0.0994 \\
{[0.0830]}\end{array}$ & $\begin{array}{l}-0.0459 \\
{[0.0493]}\end{array}$ \\
\hline Male teacher & $\begin{array}{c}0.0235 \\
{[0.0545]}\end{array}$ & $\begin{array}{c}0.0912 \\
{[0.0701]}\end{array}$ & & $\begin{array}{c}0.022 \\
{[0.0561]}\end{array}$ \\
\hline Permanent teacher & $\begin{array}{l}0.1843 * * \\
{[0.0590]}\end{array}$ & $\begin{array}{l}0.1863^{*} \\
{[0.0735]}\end{array}$ & $\begin{array}{l}0.1830 \sim \\
{[0.0929]}\end{array}$ & $\begin{array}{l}0.2261 * * \\
{[0.0726]}\end{array}$ \\
\hline Teacher holds at least one license & $\begin{array}{c}-0.1783^{* *} \\
{[0.0525]}\end{array}$ & $\begin{array}{c}-0.2154 * * \\
{[0.0577]}\end{array}$ & $\begin{array}{c}-0.2146^{* *} \\
{[0.0712]}\end{array}$ & $\begin{array}{c}-0.1910^{* *} \\
{[0.0564]}\end{array}$ \\
\hline Asian Teacher & $\begin{array}{c}-0.0575 \\
{[0.1592]}\end{array}$ & $\begin{array}{c}-0.2147 \\
{[0.2466]}\end{array}$ & & $\begin{array}{c}-0.0895 \\
{[0.1664]}\end{array}$ \\
\hline African-American teacher & $\begin{array}{c}-0.1676^{* *} \\
{[0.0473]}\end{array}$ & $\begin{array}{c}-0.2476^{* *} \\
{[0.0585]}\end{array}$ & & $\begin{array}{l}-0.1206 \sim \\
{[0.0646]}\end{array}$ \\
\hline Hispanic Teacher & $\begin{array}{c}0.0229 \\
{[0.1110]}\end{array}$ & $\begin{array}{c}0.025 \\
{[0.1259]}\end{array}$ & & $\begin{array}{c}0.0474 \\
{[0.1134]}\end{array}$ \\
\hline Student attendance (school mean) & $\begin{array}{c}0.0235 \\
{[0.0545]}\end{array}$ & $\begin{array}{c}0.0912 \\
{[0.0701]}\end{array}$ & & $\begin{array}{c}0.0264 \\
{[0.0177]}\end{array}$ \\
\hline $\begin{array}{l}\text { Percentage of students who received one or } \\
\text { more out-of-school suspensions }\end{array}$ & $\begin{array}{l}0.0289 \sim \\
{[0.0166]}\end{array}$ & $\begin{array}{l}0.0329 \sim \\
{[0.0172]}\end{array}$ & $\begin{array}{c}0.0232 \\
{[0.0266]}\end{array}$ & $\begin{array}{c}-0.0140^{* *} \\
{[0.0047]}\end{array}$ \\
\hline $\mathrm{K}-8$ range of grades & $\begin{array}{c}-1.4002 * * \\
{[0.3953]}\end{array}$ & $\begin{array}{l}-1.2666^{*} \\
{[0.5007]}\end{array}$ & & $\begin{array}{c}-1.4247^{* *} \\
{[0.3896]}\end{array}$ \\
\hline Square-root of enrollment & $\begin{array}{l}-0.0072 \\
{[0.0047]}\end{array}$ & $\begin{array}{l}-0.0051 \\
{[0.0062]}\end{array}$ & $\begin{array}{c}0.0117 \\
{[0.0183]}\end{array}$ & $\begin{array}{l}-0.0074 \\
{[0.0050]}\end{array}$ \\
\hline $\begin{array}{l}\text { (K-8 range of grades)*(square-root of } \\
\text { enrollment) }\end{array}$ & $\begin{array}{c}0.0680 * * \\
{[0.0169]}\end{array}$ & $\begin{array}{l}0.0711^{* *} \\
{[0.0221]}\end{array}$ & & $\begin{array}{l}0.0685^{* *} \\
{[0.0166]}\end{array}$ \\
\hline $\log ($ commuting distance +1$)$ & $\begin{array}{c}0.0064 \\
{[0.0231]}\end{array}$ & $\begin{array}{c}0.0196 \\
{[0.0315]}\end{array}$ & $\begin{array}{c}0.1195 \\
{[0.0760]}\end{array}$ & $\begin{array}{c}0.0085 \\
{[0.0237]}\end{array}$ \\
\hline
\end{tabular}




\begin{tabular}{|c|c|c|c|c|}
\hline Prior math achievement & $\begin{array}{l}0.3636^{* *} \\
{[0.0109]}\end{array}$ & $\begin{array}{l}0.3697 * * \\
{[0.0136]}\end{array}$ & $\begin{array}{l}0.3680 * * \\
{[0.0141]}\end{array}$ & $\begin{array}{l}0.3637 * * \\
{[0.0110]}\end{array}$ \\
\hline Prior reading achievement & $\begin{array}{l}0.2022 * * \\
{[0.0107]}\end{array}$ & $\begin{array}{l}0.2141^{* *} \\
{[0.0127]}\end{array}$ & $\begin{array}{l}0.2125^{* *} \\
{[0.0130]}\end{array}$ & $\begin{array}{l}0.2009^{* *} \\
{[0.0107]}\end{array}$ \\
\hline Square of prior math achievement & $\begin{array}{l}0.0119 \sim \\
{[0.0063]}\end{array}$ & $\begin{array}{c}0.0107 \\
{[0.0087]}\end{array}$ & $\begin{array}{c}0.0093 \\
{[0.0091]}\end{array}$ & $\begin{array}{l}0.0114 \sim \\
{[0.0065]}\end{array}$ \\
\hline Square of prior reading achievement & $\begin{array}{l}0.0372 * * \\
{[0.0064]}\end{array}$ & $\begin{array}{l}0.0375^{* *} \\
{[0.0080]}\end{array}$ & $\begin{array}{l}0.0367 * * \\
{[0.0083]}\end{array}$ & $\begin{array}{l}0.0377 * * \\
{[0.0065]}\end{array}$ \\
\hline Female student & $\begin{array}{c}0.0053 \\
{[0.0142]}\end{array}$ & $\begin{array}{c}0.0003 \\
{[0.0172]}\end{array}$ & $\begin{array}{l}-0.0007 \\
{[0.0171]}\end{array}$ & $\begin{array}{c}0.0055 \\
{[0.0143]}\end{array}$ \\
\hline Asian student & $\begin{array}{l}0.2972 * * \\
{[0.0366]}\end{array}$ & $\begin{array}{l}0.3333^{* *} \\
{[0.0443]}\end{array}$ & $\begin{array}{l}0.3352 * * \\
{[0.0433]}\end{array}$ & $\begin{array}{l}0.2964^{* *} \\
{[0.0370]}\end{array}$ \\
\hline Hispanic student & $\begin{array}{l}0.0841 * * \\
{[0.0201]}\end{array}$ & $\begin{array}{l}0.0873 * * \\
{[0.0234]}\end{array}$ & $\begin{array}{l}0.0855^{* *} \\
{[0.0239]}\end{array}$ & $\begin{array}{l}0.0822 * * \\
{[0.0202]}\end{array}$ \\
\hline White student & $\begin{array}{l}0.1688^{* *} \\
{[0.0288]}\end{array}$ & $\begin{array}{l}0.1286^{* *} \\
{[0.0344]}\end{array}$ & $\begin{array}{l}0.1227 * * \\
{[0.0345]}\end{array}$ & $\begin{array}{l}0.1672 * * \\
{[0.0290]}\end{array}$ \\
\hline $\begin{array}{l}\text { Student eligible for free or reduced-priced } \\
\text { lunch }\end{array}$ & $\begin{array}{l}-0.0557^{*} \\
{[0.0229]}\end{array}$ & $\begin{array}{c}-0.0836 * * \\
{[0.0263]}\end{array}$ & $\begin{array}{c}-0.0828 * * \\
{[0.0260]}\end{array}$ & $\begin{array}{l}-0.0560^{*} \\
{[0.0230]}\end{array}$ \\
\hline Repeated 3rd grade & $\begin{array}{c}-0.1850^{* *} \\
{[0.0217]}\end{array}$ & $\begin{array}{c}-0.1831^{* *} \\
{[0.0249]}\end{array}$ & $\begin{array}{c}-0.1880^{* *} \\
{[0.0250]}\end{array}$ & $\begin{array}{c}-0.1872 * * \\
{[0.0219]}\end{array}$ \\
\hline Repeating 4th grade & $\begin{array}{c}0.0293 \\
{[0.0358]}\end{array}$ & $\begin{array}{c}0.035 \\
{[0.0432]}\end{array}$ & $\begin{array}{c}0.0306 \\
{[0.0428]}\end{array}$ & $\begin{array}{c}0.0273 \\
{[0.0362]}\end{array}$ \\
\hline $\begin{array}{l}\text { Receives special education: included at } \\
\text { least } 3 / 4 \text { time }\end{array}$ & $\begin{array}{c}-0.0428 \\
{[0.0282]}\end{array}$ & $\begin{array}{l}-0.0273 \\
{[0.0340]}\end{array}$ & $\begin{array}{c}-0.0289 \\
{[0.0344]}\end{array}$ & $\begin{array}{l}-0.0474 \sim \\
{[0.0277]}\end{array}$ \\
\hline $\begin{array}{l}\text { Receives special } \\
\text { than } 3 / 4 \text { time }\end{array}$ & $\begin{array}{c}-0.1070^{* *} \\
{[0.0392]}\end{array}$ & $\begin{array}{l}-0.0608 \\
{[0.0500]}\end{array}$ & $\begin{array}{l}-0.0599 \\
{[0.0503]}\end{array}$ & $\begin{array}{c}-0.1072 * * \\
{[0.0395]}\end{array}$ \\
\hline $\begin{array}{l}\text { Ratio of number of } 4 \text { th graders in } \\
\text { classroom to number with test scores }\end{array}$ & $\begin{array}{c}-0.205 \\
{[0.1819]}\end{array}$ & $\begin{array}{c}-0.1169 \\
{[0.2074]}\end{array}$ & $\begin{array}{l}-0.1715 \\
{[0.2348]}\end{array}$ & $\begin{array}{l}-0.1724 \\
{[0.1871]}\end{array}$ \\
\hline SY03 & $\begin{array}{c}-0.3511^{* *} \\
{[0.0663]}\end{array}$ & $\begin{array}{c}-0.3319^{* *} \\
{[0.0814]}\end{array}$ & $\begin{array}{c}-0.3301 * * \\
{[0.1013]}\end{array}$ & $\begin{array}{c}-0.3647 * * \\
{[0.0675]}\end{array}$ \\
\hline SY04 & $\begin{array}{c}-0.0914 \\
{[0.0643]}\end{array}$ & $\begin{array}{l}-0.0736 \\
{[0.0776]}\end{array}$ & $\begin{array}{c}-0.07 \\
{[0.0957]}\end{array}$ & $\begin{array}{l}-0.1169 \sim \\
{[0.0654]}\end{array}$ \\
\hline Constant & $\begin{array}{l}-2.3252 \\
{[1.5425]}\end{array}$ & $\begin{array}{l}-2.7960 \sim \\
{[1.6270]}\end{array}$ & $\begin{array}{c}-2.3652 \\
{[2.4383]}\end{array}$ & $\begin{array}{l}-2.0267 \\
{[1.6591]}\end{array}$ \\
\hline & & & & $8 / 13$ \\
\hline Unique teachers & 285 & 144 & 144 & 285 \\
\hline
\end{tabular}


Within teacher variance

$\begin{array}{llll}0.402 & 0.408 & 0.409 & 0.402 \\ 0.204 & 0.187 & 0.268 & 0.211 \\ 0.729 & 0.707 & 0.560 & 0.722 \\ 0.357 & 0.364 & 0.363 & 0.357 \\ 0.498 & 0.482 & 0.431 & 0.497\end{array}$

Intraclass correlation

Between teacher R-squared

Within teacher R-squared

$\sim \mathrm{p}<.1 ; * \mathrm{p}<.05 ; * * \mathrm{p}<.01$

Notes:

a. The reference group for teacher experience comprises teachers with 10 or more years of experience, 46 percent of the analytic sample. 
Figure 1. Adjusted mean values of discretionary absences, ${ }^{a}$ by school, displayed in ascending order. The black bar indicates the overall adjusted mean of 5.13 days $(S D=1.12) .(2,594$ unique teachers in 75 schools over three academic years)

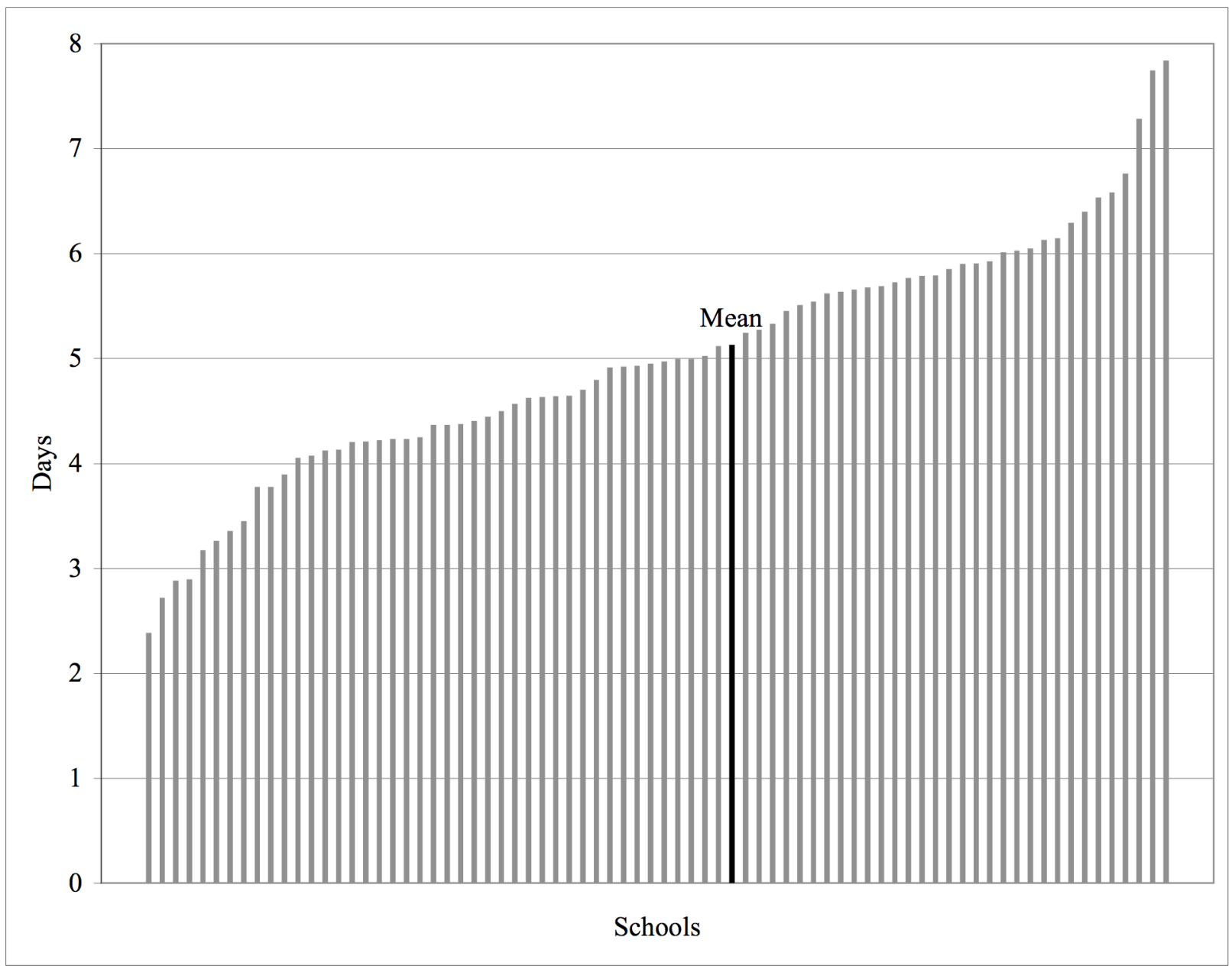

Notes:

a. Means adjusted for fixed-effects of academic years and observed characteristics of individual teachers in the schools: gender, ethnicity, commuting distance, licensure status, permanent employment status, and teaching experience. 
Figure 2. Mean of predicted daily absence over three academic years, by bins defined by a teacher's commuting distance and the severity of the weather in the vicinity of her home (2,594 unique teachers).

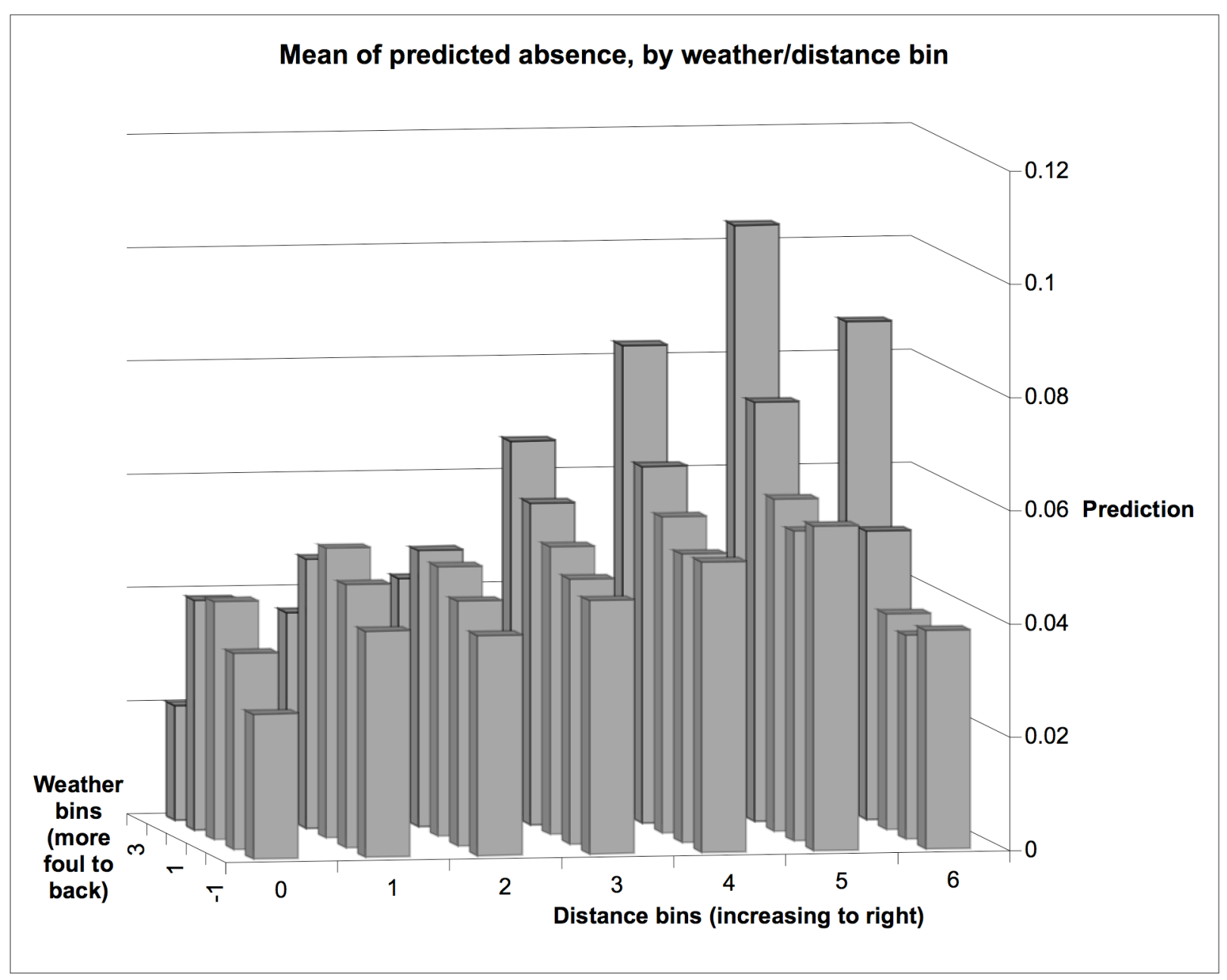




\section{APPENDICES}

Appendix A: Table of stage one results

Table A1. Parameter estimates, [robust standard errors], approximate p-values, and goodnessof-fit statistics for a regression model fit to a dataset in which a the unit of analysis is a teacherday and the outcome is a dichotomous indicator of teacher absence.

Predictor

Foul weather index ${ }^{\mathrm{a}}$

$0.0039 * *$

Square of foul weather index

[0.0012]

$-0.0014^{*}$

(Foul weather index $) *(\log ($ distance $))$

[0.0006]

$-0.0011 \sim$

[0.0006]

(Square of foul weather index $) *(\log ($ distance $))$

$0.0007^{*}$

[0.0003]

Log(commuting distance)

0.0005

[0.0031]

Teacher has 1 or 2 years of experiencee ${ }^{b}$

$-0.007$

Teacher has 3 or 4 years of experience

[0.0070]

$-0.0081$

[0.0066]

Teacher has 5 to 9 years of experience

$-0.0036$

[0.0065]

Male teacher

0.0041

Permanent teacher

[0.0068]

$0.0229 * *$

[0.0048]

Teacher holds at least one license

$-0.0069 \sim$

[0.0042]

Asian Teacher

$-0.0205$

[0.0219]

African-American teacher

$0.0219 * *$

[0.0064]

Hispanic Teacher

0.0043

[0.0100]

Student attendance (school mean)

$-0.0018$

[0.0016]

Percentage of students who received one or more out-of-school suspensions

$-0.0004$

[0.0005]

$\mathrm{K}-8$ range of grades

$-0.0262$

[0.0364]

Square-root of enrollment

$-0.0004$ 
(K-8 range of grades)*(square-root of enrollment)

[0.0006]

0.0008

[0.0016]

Prior math achievement ${ }^{\mathrm{c}}$

0.0073

[0.0059]

Prior reading achievement

$-0.0102 * *$

[0.0031]

Square of prior math achievement

$-0.0173 * *$

[0.0059]

Square of prior reading achievement

$0.0130 * *$

[0.0033]

Female student

0.0146

[0.0110]

Asian student

$-0.0005$

[0.0162]

Hispanic student

$-0.0158 \sim$

[0.0091]

White student

$-0.014$

[0.0134]

0.0035

[0.0129]

$-0.0272$

[0.0203]

Repeating 4th grade

$-0.0294$

[0.0225]

Receives special education: included at least 3/4 time

$-0.0702 * *$

[0.0170]

Receives special education: included less than 3/4 time

0.013

$[0.0235]$

(Number of 4 th graders in classroom)/(number with test scores)

$-0.0044$

[0.0158]

SY03

$-0.0103 *$

[0.0052]

SY04

$-0.0166^{* *}$

[0.0051]

Constant

0.2374

[0.1506]

Teacher-day observations 89191

Unique teachers 285

Between-teacher variance

0.0021

Within teacher variance

0.0409

Intraclass correlation

0.0484

Between teacher R-squared

0.1358 
Within teacher R-squared $\quad 0.001$

Overall R-squared

0.0074

$\sim \mathrm{p}<.1 ; * \mathrm{p}<.05 ; * * \mathrm{p}<.01$

Notes:

a. We conducted tests of hypotheses concerning the relevance of the instruments to the model. First, we tested the null that the parameters associated with the foul weather index and its square are simultaneously zero. We rejected this null hypotheses $(p<.01)$. Second, note that the interactions between the log of distance and both the foul weather index and its square vary at the teacher-day level. Thus, it is not possible to include these interactions in the second stage (where the unit of analysis is the student-teacher-day). This omission has the effect of treating the interactions as exogenous instruments, so we tested the null hypothesis that the parameters associated with all four predictors involving the foul weather index are simultaneously zero. We rejected this null $(\mathrm{p}<.001)$. We included a quadratic polynomial function of both measures of prior student achievement (mathematics and reading) as a control for the entire academic background before $4^{\text {th }}$ grade. Each of the four estimated parameters was significant $(\mathrm{p}<.01)$ in all three specifications. In addition, our models included controls for students' gender, ethnicity, and status with respect to living in poverty, first language being English, receiving Special Education, grade repetition.

b. The reference group for teacher experience comprises teachers with 10 or more years of experience, 46 percent of the analytic sample.

c. Variables that vary by student in the second stage of our modeling strategy are included in this first stage as classroom means. We also fit the first stage without these classroom means, which had little effect on model fit. However, the estimate of interest at the second stage - the effect of yearly absences before the achievement tests - is reduced by roughly half in this case. We favor including theses classroom means at in the first stage of our estimation strategy because of their clearly endogenous nature.

\section{Appendix B: Standard Error Adjustment}

Our indirect 2SLS strategy requires manipulation of estimates in order to obtain correct standard errors. This appendix describes the general process we used. Stata code is available from the authors.

The key to the standard error correction procedure involves adjusting the second stage variance-covariance matrix. The necessary ideas and suggested approach to forming an adjustment scalar are documented in the Stata technical database ${ }^{19}$ The adjustment scalar is formed by taking a ratio of two mean squared error values. The numerator is the mean squared

\footnotetext{
${ }^{19}$ See "Two-stage least squares regression” by Vince Wiggins, updated July, 2005.
} 
error corresponding to the second-stage estimation using the endogenous predictor. The denominator is the mean squared error corresponding to the second-stage estimation using the exogenous predictor (aggregated estimates from the first stage). This estimation step, of course, produces the point estimate of interest, but the estimated standard error is artificially low. The correction scalar, being greater than unity, inflates the standard errors

Unfortunately, the most straightforward way of creating this scalar does not apply to the situation in which the data have a nested structure. The procedure uses the regress command, but our preferred command for fitting second-stage models is $x$ treg. In order to produce estimated standard errors that respect the nesting of students within classrooms at stage-two of our 2SLS strategy, a preliminary data transformation step is required. By combining the $x t d a t a$ and regress commands, one can duplicate the results of xtreg. Random effects requires estimation of the square root of the ratio of between and within variance components of the fitted second-stage model.

Earlier versions of this paper afford us some confidence that our departure from the conventional approach to adjusting the standard errors is correct. In particular, by aggregating daily information on absence and weather, we were able to produce a student-teacher-year dataset in which the unit of analysis at both stages of our 2SLS strategy were the same. Thus, we could fit models simultaneously with xtivreg or in the indirect method described above. We obtained identical results. In this paper, we are unable to use a MLE-based simultaneous equation modeling approach to provide estimated standard errors because of the aggregation step inherent in our strategy. This step is necessary in order to reconcile the units of the first stage estimates and the second stage outcome. 